Postgraduate Bosowa University Publishing (PBUP)
Indonesian Journal of Business and Management
https://postgraduate.universitasbosowa.ac.id/index.php/jbm

\title{
PENGARUH GAYA KEPEMIMPINAN, MOTIVASI DAN DISIPLIN KERJA TERHADAP KINERJA PEGAWAI PADA DINAS DUKCAPIL KABUPATEN SINJAI
}

\section{The Influence of Leadership Style, Motivation and Work Discipline on Employee Performance in the Population and Civil Registration Office of Sinjai Regency}

\author{
Nurhanan ${ }^{1}$, Hasanuddin Remmang ${ }^{2}$, Miah Said $^{2}$ \\ ${ }^{1}$ Dinas Kependudukan dan Pencatatan Sipil Kabupaten Sinjai \\ ${ }^{2}$ Program Studi Manajemen Program Pascasarjana Universitas Bosowa \\ Email: hana.alwi@gmail.com
}

Diterima: 04 Maret 2020 /Disetujui: 05 Juni 2020

\begin{abstract}
ABSTRAK
Penelitian ini bertujuan untuk menganalisis pengaruh gaya kepemimpinan, motivasi dan disiplin kerja terhadap kinerja pegawai pada Dinas Kependudukan dan Pencatatan Sipil Kabupaten Sinjai. Dimana rumusan masalahnya adalah bagaimana pengauh gaya kepemimpinan, motivasi dan disiplin kerja terhadap kinerja pegawai pada dinas dukcapil Kabupaten Sinjai. Tujuannya untuk mengetahui hubungan dan pengaruh gay kepemimpinan motivasi dan disiplin kerja pada kinerja pegawai dias Dukcapil Kabupaten Sinjai. Metode dan teknik analisis data yang digunakan adalah metode kuantitatif dengan teknik analisis data menggunakan analisis Regresi Linier Berganda dari 30 responden yang dijadikan populasi dan sample (full sampling). Hasil penelitian ini menunjukkan bahwa secara simultan dan parsial gaya kepemimpinan, motivasi dan disiplin kerja berpengaruh positif dan signifikan terhadap kinerja pegawai. Ditemukan bahwa disiplin kerja paling dominan berpengaruh terhadap kinerja pegawai pada Dinas Kependudukan dan Pencatatan Sipil Kabupaten Sinjai.
\end{abstract}

Kata Kunci: Gaya Kepemimpinan, Motivasi, Disiplin Kerja, Kinerja.

\begin{abstract}
This study aims to analyze the influence of leadership style, motivation and work discipline on employees' performance at the Population and Civil Registration Office of Sinjai Regency. The research question is how the leadership style, motivation and work discipline influence employees' performance at the Population and Civil Registration Office of Sinjai Regency. The aim is to determine the relationship and the influence of leadership style, motivation and work discipline on the performance of employees at the Population and Civil Registration Office of Sinjai Regency. Data analysis methods and techniques used are quantitative methods with data analysis techniques using Multiple Linear Regression analysis where 30 respondents used as population and sample (full sampling). The results of this study indicate that simultaneously and partially leadership style, motivation and work discipline have a positive and significant effect on employees' performance. It was found that work discipline mostly dominantly affected the performance of employees at the Dinas Kependudukan dan Pencatatan Sipil in Sinjai Regency.
\end{abstract}

Keywords: Leadership Style, Motivation, Work Discipline, Performance

\section{PENDAHULUAN}

Instansi pemerintah adalah organisasi yang merupakan kumpulan orang-orang yang dipilih secara khusus untuk melaksanakan tugas Negara sebagai bentuk pelayanan kepada orang banyak. Tujuan instansi pemerintah dapat dicapai apabila mampu mengolah, menggerakkan dan menggunakan sumber daya manusia yang dimiliki secara efektif dan efisien. Peran manusia dalam organisasi sebagai pegawai memegang peranan yang menentukan karena hidup matinya suatu organisasi pemerintah semata-mata tergantung pada manusia sebagai penggeraknya. Pegawai merupakan faktor penting dalam setiap organisasi pemerintahan dikarenakan pegawai merupakan faktor penentu dalam pencapaian tujuan instansi secara efektif dan efisien. 
Dinas Kependudukan dan Pencatatan Sipil Kabupaten Sinjai merupakan salah satu instansi milik negara yang bergerak di bidang kependudukan dan pencatatan sipil yang mempunyai tugas pokok membantu bupati dalam melaksanakan kewenangan pemerintah daerah dalam merumuskan, membina, mengendalikan dan mengelola serta mengkoordinir kebijakan yang terkait dengan kependudukan. Capaian kinerja pegawai Dinas Kependudukan dan Pencatatan Sipil Kabupaten Sinjai selama dua tahun terakhir mengalami penurunan. Namun demikian, kinerja pegawai secara keseluruhan masih dalam kategori baik. Capaian kinerja tersebut juga merupakan refleksi dari tata kelola Dinas Kependudukan dan Pencatatan Sipil Kabupaten Sinjai yang telah menunjukkan standar pelayanan prima yang baik. Hal tersebut kemudian menimbulkan sejumlah dugaan bahwa keberhasilan tata kelola pemerintahan sangat terkait dengan banyak faktor, seperti gaya kepemimpinan, motivasi, dan disiplin kerja pegawai.

Keberhasilan suatu organisasi dalam mencapai suatu tujuan ditentukan dari mutu profesionalisme yang ditentukan oleh disiplin para pegawainya, bagi aparatur pemerintah disiplin tersebut merupakan unsur ketaatan, kesetiaan, kesungguhan dalam menjalankan tugas dan kesanggupan berkorban dalam arti mengorbankan kepentingan pribadi dan golongan untuk kepentingan masyarakat dan negara (Hastati et al, 2020).

Disiplin aparatur sipil negara adalah kesanggupan aparatur sipil negara untuk mentaati kewajiban dan menghindari larangan yang sudah ditetapkan dalam peraturan perundang-undangan dan/atau peraturan kedinasan yang apabila tidak ditaati atau dilanggar dijatuhi hukuman disiplin, sedangkan pelanggaran disiplin adalah ucapan, tulisan ataupun perbuatan aparatur sipil negara yang tidak mentaati kewajiban dan/atau melanggar larangan ketentuan disiplin yang dilakukan didalam maupun diluar jam kerja. Peraturan Aparatur Sipil Negara sudah diatur dalam Peraturan Pemerintah Nomor 53 Tahun 2010 tentang "Disiplin Pegawai Negeri Sipil" dimana dalam peraturan tersebut sudah diatur ketentuanketentuan mengenai kewajiban, Larangan dan Jenis dan Hukum Disiplin PNS yang harus dipahami dan ditaati.

Banyak hal yang dapat mempengaruhi produktivitas kerja, untuk itu instansi pemerintah harus mampu menjamin agar faktor yang berkaitan dengan produktifitas dapat dipenuhi secara maksimal, diantaranya gaya kepemimpinan, motivasi dan disiplin kerja. Dalam suatu organisasi, kepemimpinan merupakan faktor yang sangat penting dalam menentukan pencapaian tujuan yang telah ditetapkan oleh organisasi. (Kelly, 2005) menyatakan bahwa kepemimpinan merupakan simpul dari karakteristik kepemimpinan dalam suatu organisasi yang sengaja dibuat untuk mampu menggerakkan, mengarahkan dan mempengaruhi orang-orang dalam organisasi untuk mencapai tujuan.

Disiplin kerja merupakan praktek secara nyata dari para pegawai terhadap perangkat peraturan yang terdapat dalam suatu organisasi. Dalam hal ini disiplin tidak hanya dalam bentuk ketaatan saja melainkan juga tanggung jawab yang diberikan oleh organisasi. Berdasarkan pada hal tersebut diharapkan efektivitas pegawai akan meningkat dan bersikap serta bertingkah laku disiplin.

Regina Aditya Reza (2010), Teguh Rhiman Handoko (2012) dan Rio Rizki Pratama (2016) telah meneliti disiplin kerja terhadap kinerja pegawai dengan hasil disiplin kerja berpengaruh positif dan signifikan terhadap kinerja pegawai. Kinerja berasal dari kata job performance atau actual performance yang berarti prestasi kerja atau prestasi sesungguhnya yang dicapai oleh seseorang. Pengertian kinerja (prestasi kerja) adalah hasil kerja secara kualitas dan kuantitas yang dicapai oleh seorang pegawai dalam melaksanakan fungsinya sesuai dengan tanggung jawab yang diberikan kepadanya.

Stolovitch \& Keeps (2007) menyatakan bahwa kinerja merupakan seperangkat hasil yang dicapai merujuk pada tindakan pencapaian serta pelaksanaan suatu pekerjaan yang diminta. Kinerja merupakan salah satu kumpulan total dari kerja yang ada pada diri pekerja (Moorhead \& Griffin 2008). Kinerja pegawai merupakan suatu hasil karya yang dicapai oleh pegawai tersebut dalam pekerjaannya menurut kriteria tertentu yang berlaku untuk suatu pekerjaan tertentu. Menurut Robbins (2006) bahwa kinerja pegawai adalah fungsi dari interaksi antara kemampuan dan motivasi.

Penelitian bertujuan untuk mengetahui dan menganalisis pengaruh gaya kepemimpinan, motivasi dan disiplin kerja terhadap kinerja pegawai serta menganalisis faktor apa yang paling dominan berpengaruh terhadap kinerja pegawai.

\section{METODE}

Pendekatan yang digunakan dalam penelitian ini adalah pendekatan penelitian deskriptif kuantitatif dengan menggunakan jenis penelitian survey yaitu penelitian dengan mengambil sampel dari populasi dengan menggunakan kuesioner sebagai alat pengumpulan data.

Menurut Arikunto (2013), populasi adalah keseluruhan dari subyek penelitian. Populasi dalam penelitian ini yakni keseluruhan Pegawai Dinas Kependudukan dan Pencatatan Sipil Kabupaten Sinjai.

Pengertian sampel menurut Riduwan (2007) mengatakan bahwa "Sampel adalah bagian dari populasi". Sampel penelitian adalah sebagian atau keseluruhan dari populasi yang diambil sebagai sumber data dan dapat mewakili seluruh populasi. Arikunto (2013) mengemukakan bahwa apabila subyek atau populasi kurang dari 100, maka sebaiknya populasi diambil semua sebagai sampel. Adapun sampel dalam penelitian ini adalah seluruh jumlah Pegawai Negeri Sipil pada Dinas Kependudukan dan Pencatatan Sipil Kabupaten Sinjai sejumlah 30 orang responden.

Variabel dalam penelitian ini terbagi dua yaitu variabel independen dan variabel dependen. Variabel independen terdiri gaya kepemimpinan, motivasi dan 
disiplin kerja, dan variabel dependennya adalah kinerja pegawai.

Metode analisis data untuk menguji data pada penelitian menggunakan metode analisis regresi linier berganda dan pengujian hipotesis (uji F, uji t dan uji determinasi).

\section{HASIL DAN PEMBAHASAN}

Gaya dasar kepemimpinan yang diterapkan dalam suatu organisasi tidak terlepas dari perilaku pemimpin dalam hal ini perilaku mengarahkan, mendukung, menggerakkan dan mempengaruhi untuk mampu mengembangkan kepemimpinan instruksi, konsultasi, partisipasi dan delegasi (Thoha, 2002). Penerapan gaya kepemimpinan yang tepat akan menimbulkan motivasi dan disiplin kerja seseorang untuk berprestasi.

Rusady Ruslan (2014), Soleman Aninam (2014) dan Rahmat Asfari (2017) telah meneliti gaya kepemimpinan terhadap kinerja pegawai dan menyatakan bahwa gaya kepemimpinan mempunyai pengaruh positif dan signifikan terhadap kinerja pegawai. Menurut Rivai (2008), istilah motivasi secara harfiah diartikan sebagai dorongan yang timbul pada diri seseorang secara sadar atau tidak sadar untuk melakukan tindakan sesuai tujuan tertentu. Istilah motivasi juga sering diartikan sebagai daya gerak, penyebab seseorang untuk melakukan berbagai aktivitas dengan tujuan tertentu. Ada lima teori motivasi yang mendukung, yaitu teori hirarki kebutuhan dari Maslow, teori X dan Y dari McGregor, teori prestasi McClelland, teori harapan dari Vroom dan teori Existence, Relatednes, and Grwth (ERG) dari Clayton Alderfer. Teori yang menjadi pengamatan utama yang digunakan pada penelitian ini mengacu pada teori ERG. Teori ERG menyebutkan ada tiga kategori kebutuhan individu yaitu eksistensi (existence), keterhubungan (relatedness) dan pertumbuhan (growth), karena itu disebut teori ERG.

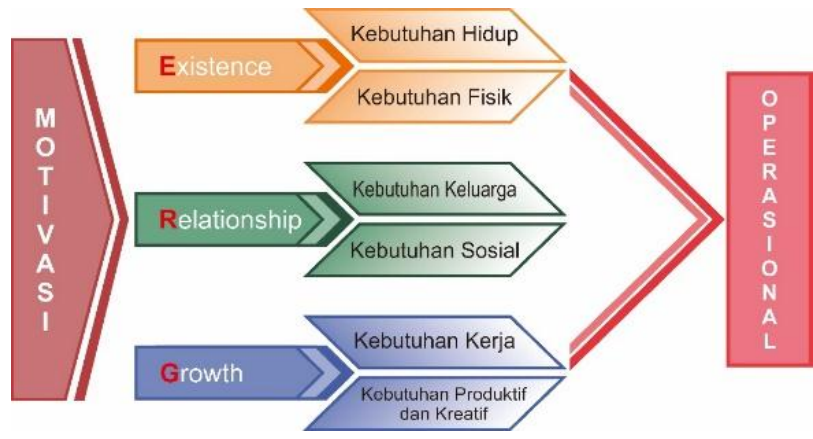

Gambar 1 Teori Motivasi ERG

Sumber: Hersey \& Blanchard (2007)

Memahami teori kebutuhan ERG, ada tiga landasan penting untuk melihat bagaimana orang termotivasi karena dorongan atau hasrat terpenuhi kebutuhan pribadinya. Ketiga landasan ini memfokuskan kepada: 1) kebutuhan eksistensi diri yaitu mengembangkan segala potensi yang dimiliki untuk memenuhi kebutuhan utamanya (need existence); 2) kebutuhan hubungan atau relationship yaitu kebutuhan untuk bersosialisasi dan berinteraksi dengan orang dan lingkungan kerjanya (need relation); dan 3) kebutuhan pertumbuhan (need growth) yaitu kebutuhan untuk memelihara prestasi hasil kerja dan pengakuan atas yang dihasilkan.

Aurelia Potu (2013), Pariaribo (2014) dan Rizham Syakban (2017) telah meneliti motivasi terhadap kinerja pegawai dengan hasil motivasi berpengaruh positif dan signifikan terhadap kinerja pegawai.

Disiplin berasal dari bahasa latin "Diciplina" yang berarti latihan atau pendidikan kesopanan dan kerohanian serta pengembangan tabiat. Jadi sifat disiplin berkaitan dengan pengembangan sikap. Moenir (2005) mengemukakan bahwa "Disiplin adalah ketaatan yang sikapnya impersonal, tidak memakai perasaan dan tidak memakai perhitungan pamrih atau kepentingan pribadi."

Adapun menurut peraturan disiplin Pegawai Negeri Sipil sebagaimana telah dimuat didalam BAB II pasal (2) UU Nomor 43 Tahun 1999, ada beberapa keharusan yang harus dilaksanakan yaitu:

a. Mentaati segala peraturan perundang-undangan dan peraturan kedinasan yang berlaku serta melaksanakan perintah-perintah kedinasan yang diberikan oleh atasan yang berhak.

b. Melaksanakan tugas dengan sebaik-baiknya serta memberikan pelayanan yang baik terhadap masyarakat sesuai dengan bidang dan tugasnya.

c. Menggunakan dan memelihara barang-barang dinas dengan sebaik-baiknya.

d. Bersikap dan bertingkah laku sopan santun terhadap masyarakat, sesama pegawai negeri sipil dan atasannya.

Hasil penelitian yang dilakukan pada Dinas Kependudukan dan Pencatatan Sipil Kabupaten Sinjai diketahui gambaran karakteristik responden sebagai berikut.

Tabel 1 Karakteristik Responden berdasarkan Jenis Kelamin

\begin{tabular}{clcc}
\hline No. & Jenis Kelamin & Frekuensi (Orang) & Persentase (\%) \\
\hline 1 & Laki-laki & 17 & 56,67 \\
2 & Perempuan & 13 & 43,33 \\
\hline \multicolumn{2}{c}{ Total } & 30 & 100,0 \\
\hline Sumber: Data Primer, 2019 & &
\end{tabular}

Berdasarkan Tabel 1 , diperoleh data bahwa responden yang paling banyak adalah berjenis kelamin laki-laki yaitu sebanyak 17 orang atau sebanyak 56.67\% dan responden berjenis kelamin perempuan ada sebanyak 13 orang atau $43.33 \%$.

Tabel 2 Karakteristik Responden berdasarkan Umur

\begin{tabular}{cccc}
\hline No & Umur (Tahun) & Frekuensi (Orang) & Persentase $(\%)$ \\
\hline 1 & $26-30$ & 1 & 3.33 \\
2 & $31-35$ & 5 & 16.67 \\
3 & $36-40$ & 10 & 33.33 \\
4 & $>40$ & 14 & 46.67 \\
\hline & Total & 30 & 100 \\
\hline
\end{tabular}

Sumber: Data Primer, 2019

Tabel 2 diperoleh data bahwa responden yang paling banyak adalah kelompok umur > 40 tahun yaitu sebanyak 14 orang atau $46.67 \%$, selanjutnya pegawai berumur 36-40 tahun yaitu sebanyak 10 orang atau 
$33.33 \%$, umur 31-35 tahun sebanyak 5 orang atau $16.67 \%$, dan 1 orang atau $3.33 \%$ berumur $26-30$ tahun. Ini menunjukkan bahwa kebanyakan pegawai pada Dinas Kependudukan dan Pencatatan Sipil Kabupaten Sinjai memiliki usia yang matang/produktif untuk menjalankan tugas pokok dan fungsinya. Umur yang dimiliki oleh pegawai dapat berpengaruh terhadap upaya peningkatan kinerja yang dicapai melalui penerapan gaya kepemimpinan, motivasi dan disiplin kerja yang dimiliki pegawai.

Tabel 3 Karakteristik Responden berdasarkan Pendidikan

\begin{tabular}{cccc}
\hline No & $\begin{array}{c}\text { Klasifikasi } \\
\text { Pendidikan }\end{array}$ & $\begin{array}{c}\text { Frekuensi } \\
\text { (Orang) }\end{array}$ & $\begin{array}{c}\text { Persentase } \\
(\%)\end{array}$ \\
\hline 1. & S2 & 7 & 23.33 \\
2. & S1 & 17 & 56.67 \\
3. & D3 & 1 & 3.33 \\
4. & SLTA & 5 & 16.67 \\
\hline & Total & 30 & 100 \\
\hline
\end{tabular}

Sumber: Data Primer, 2019

Tabel 3 diperoleh data responden pegawai yang secara umum berpendidikan S1 yaitu sebanyak 17 orang atau $56.67 \%$, kemudian yang berpendidikan S2 sebanyak 7 orang atau $23.33 \%$, pegawai berpendidikan SMA sebanyak 5 orang atau $16.67 \%$ dan 1 orang atau 3.33\% yang berpendidikan D3. Ini menunjukkan bahwa pendidikan yang dimiliki oleh responden berperan penting dan sesuai dengan bidang tugas yang ditekuni, yaitu ratarata responden telah berpendidikan S1, sehingga menjadi pertimbangan bagi setiap pimpinan untuk memberikan peluang kepada pegawai untuk melanjutkan pendidikan ke jenjang yang lebih tinggi dan memberikan peluang menduduki jabatan yang lebih baik.

Analisis data dalam penelitian ini menggunakan uji regresi linier berganda yang bertujuan untuk memperoleh gambaran yang menyeluruh mengenai pengaruh variabel gaya kepemimpinan, motivasi dan disiplin kerja terhadap kinerja pegawai pada Dinas Kependudukan dan Pencatatan Sipil Kabupaten Sinjai. Hasil analisis dan menggunakan regresi linier berganda ditunjukkan pada tabel di bawah ini.

Tabel 4 Hasil Uji Regresi Linier Berganda

Coefficients $^{\mathrm{a}}$

\begin{tabular}{lccccc}
\hline \multirow{2}{*}{ Model } & \multicolumn{2}{c}{ Unstandardized Coefficients } & Standardized Coefficients & t & Sig. \\
\cline { 2 - 7 } & $\mathrm{B}$ & Std. Error & Beta & & \\
\hline (Constant) & 2,302 & 7,539 & 0,441 & 0,305 & 0,763 \\
Gaya Kepemimpinan & 0,427 & 0,115 & 0,446 & 3,708 & 0,001 \\
Motivasi & 0,439 & 0,117 & 0,483 & 3,738 & 0,001 \\
Disiplin Kerja & 0,461 & 0,114 & 4,049 & 0,000 \\
\hline
\end{tabular}

a. Dependent Variable: Kinerja Pegawai

Sumber: Hasil olah data dengan SPSS 25.0 (2019)

Pada Tabel 4 coefficients yang diinterpretasikan adalah nilai dalam kolom B, baris pertama menunjukkan Konstanta (a) dan baris selanjutnya menunjukkan koefisien regresi variabel independen (b). berdasarkan hasil analisis yang ditunjukkan pada tabel 4 didapatkan persamaan regresi linier berganda antara gaya kepemimpinan, motivasi dan disiplin kerja dengan kinerja pegawai sebagai berikut:

Keterangan

$$
\mathrm{Y}=2,302+0,427 \mathrm{X}_{1}+0,439 \mathrm{X}_{2}+0,461 \mathrm{X}_{3}
$$

Y : Kinerja Pegawai

$\mathrm{X}_{1}$ : Gaya Kepemimpinan

$\mathrm{X}_{2}:$ :Motivasi

$\mathrm{X}_{3}$ : Disiplin Kerja

Hasil persamaan regresi linier berganda tersebut di atas maka dapat dianalisis sebagai berikut:

1) Konstanta sebesar 2,302, artinya jika variabel gaya kepemimpinan, motivasi dan disiplin kerja dianggap konstan (0) atau tidak ada perubahan, maka variabel kinerja pegawai sebesar 2,302.

2) Koefisien regresi gaya kepemimpinan sebesar 0,427, artinya jika variabel motivasi dan disiplin kerja dianggap konstan (0) atau tidak ada perubahan, maka setiap peningkatan gaya kepemimpinan sebesar 1 satuan akan memberikan pengaruh peningkatan kinerja pegawai sebesar 0,427.
3) Koefisien regresi motivasi sebesar 0,439 , artinya jika variabel gaya kepemimpinan dan disiplin kerja dianggap konstan (0) atau tidak ada perubahan, maka setiap peningkatan motivasi sebesar 1 satuan akan memberikan pengaruh peningkatan kinerja pegawai sebesar 0,439.

4) Koefisien regresi disiplin kerja sebesar 0,461, artinya jika variabel gaya kepemimpinan dan motivasi dianggap konstan (0) atau tidak ada perubahan, maka setiap peningkatan disiplin kerja sebesar 1 satuan akan memberikan pengaruh peningkatan kinerja pegawai sebesar 0,461 .

Persamaan regresi linier berganda di atas menunjukkan bahwa variabel bebas yang paling berpengaruh terhadap kinerja pegawai adalah variabel disiplin kerja dengan koefisien regresi 0,461, selanjutnya variabel motivasi dengan koefisien regresi 0,439 dan variabel gaya kepemimpinan dengan koefisien regresi 0,427 . Selain itu persamaan tersebut menunjukkan bahwa variabel gaya kepemimpinan, motivasi dan disiplin kerja memiliki pengaruh positif terhadap kinerja pegawai. Hal ini berarti semakin baik gaya kepemimpinan, motivasi dan disiplin kerja akan mengakibatkan peningkatan kinerja pegawai.

Untuk mengetahui signifikan tidaknya pengaruh gaya kepemimpinan, motivasi dan disiplin kerja secara 
simultan terhadap kinerja pegawai dengan menggunakan uji F yang hasilnya ditunjukkan pada Tabel 5di bawah ini.

Tabel 5 Hasil Uji F

\begin{tabular}{clccccc}
\multicolumn{6}{c}{ ANOVA $^{\mathrm{a}}$} \\
\hline & Model & $\begin{array}{c}\text { Sum of } \\
\text { Squares }\end{array}$ & df & $\begin{array}{c}\text { Mean } \\
\text { Square }\end{array}$ & F & Sig. \\
\hline 1 & Regression & 287,135 & 3 & 95,712 & 14,961 &, $000^{\mathrm{b}}$ \\
& Residual & 166,332 & 26 & 6,397 & & \\
& Total & 453,467 & 29 & & & \\
\hline a. & Dependent Variable: Kinerja (Y) & & & \\
b. & $\begin{array}{l}\text { Predictors: (Constant), Disiplin } \\
\text { Gerja (X3), Motivasi }\end{array}$ & (X2), \\
Sumber: Hasil olah data dengan SPSS 25.0 (2019) & & &
\end{tabular}

Tabel 5 menunjukkan bahwa nilai $F_{\text {hitung }}$ sebesar 14,961 dengan nilai signifikan (Sig.) sebesar 0,000. Diketahui pada taraf signifikan $(\alpha) 0,05$ jumlah sampel (n) 30, derajat bebas ke-1 $\left(\mathrm{df}_{1}\right)=\mathrm{k}=3$ dan derajat bebas ke-2 $\left(\mathrm{df}_{2}\right)=\mathrm{n}-\mathrm{k}-1=26$ diperoleh nilai $\mathrm{F}_{\text {tabel }}$ sebesar 2,975 . Oleh karena nilai $F_{\text {hitung }}(14,961)>F_{\text {tabel }}(2,975)$ dan nilai signifikan $(0,000)<0,05$ maka hipotesis $H_{o}$ ditolak dan $\mathrm{H}_{\mathrm{a}}$ diterima, yang berarti terdapat pengaruh signifikan gaya kepemimpinan, motivasi dan disiplin kerja secara simultan terhadap kinerja pegawai pada Dinas Kependudukan dan Pencatatan Sipil Kabupaten Sinjai.

Besarnya pengaruh variabel gaya kepemimpinan, motivasi dan disiplin kerja secara bersama-sama (simultan) terhadap kinerja pegawai pada Dinas Kependudukan dan Pencatatan Sipil Kabupaten Sinjai ditunjukkan dengan besarnya nilai koefisien determinan $\left(\mathrm{R}^{2}\right)$ sebagaimana ditampilkan pada tabel di bawah ini.

Tabel 6 Koefisien Determinasi

\begin{tabular}{|c|c|c|c|c|}
\hline Model & $\mathrm{R}$ & $\begin{array}{c}\mathrm{R} \\
\text { Square }\end{array}$ & $\begin{array}{l}\text { Adjusted R } \\
\text { Square }\end{array}$ & $\begin{array}{l}\text { Std. Error of the } \\
\text { Estimate }\end{array}$ \\
\hline 1 &, $796^{\mathrm{a}}$ & 0,633 & 0,591 & 2,529 \\
\hline \multicolumn{5}{|c|}{$\begin{array}{l}\text { a. Predictors: (Constant), Disiplin Kerja (X3), Motivasi (X2), Gaya } \\
\text { Kepemimpinan (X1) } \\
\text { b. Dependent Variable: Kinerja Pegawai (Y) }\end{array}$} \\
\hline \multicolumn{5}{|c|}{ Sumber: Hasil olah data dengan SPSS 25.0 (2019) } \\
\hline
\end{tabular}

determinasi $\left(\mathrm{R}^{2}\right)$ sebesar 0,633 . Hal ini berarti $63,3 \%$ kinerja pegawai dipengaruhi oleh variabel gaya kepemimpinan, motivasi dan disiplin kerja, sedangkan sisanya $36,7 \%$ dipengaruhi oleh faktor-faktor lain yang tidak diteliti pada penelitian ini.

\section{Pengaruh Gaya Kepemimpinan terhadap Kinerja Pegawai}

Persepsi responden terhadap gaya kepemimpinan dianggap merupakan faktor yang cukup baik pengaruhnya terhadap kinerja pegawai. Hasil analisis regresi linier berganda dan pengujian secara parsial (uji t) terhadap variabel gaya kepemimpinan menunjukkan bahwa gaya kepemimpinan berpengaruh positif dan signifikan terhadap kinerja pegawai. Artinya secara parsial dapat dinyatakan jika terjadi peningkatan atau penurunan pada variabel gaya kepemimpinan akan mempengaruhi peningkatan ataupun penurunan kinerja pegawai.

Penerapan gaya kepemimpinan yang berupa gaya instruksi, konsultasi, partisipasi dan delegasi memberikan pengaruh dalam meningkatkan kinerja pegawai pada Dinas Kependudukan dan Pencatatan Sipil Kabupaten Sinjai. Hal ini penting mengingat keberhasilan suatu organisasi banyak ditentukan oleh kemampuan seorang pemimpin dalam mengembangkan gaya kepemimpinannya untuk mempengaruhi, menggerakkan dan mengikutsertakan bawahannya secara aktif dalam meningkatkan kinerja agar tujuan organisasi tercapai.

Analisis deskripsi variabel gaya kepemimpinan, indikator partisipasi dan instruksi memiliki skor yang paling tinggi. Hal ini dipahami bahwa penerapan gaya kepemimpinan partisipasi dan instruksi cukup berhasil dimana pimpinan dapat memberikan arahan pada bawahannya untuk mematuhi dan mentaati perintahnya dalam melaksanakan tugas. Pimpinan juga ikut berpartisipasi dalam kegiatan-kegiatan yang dilakukan serta memberi teladan yang baik pada bawahannya. Sementara indikator konsultasi memiliki skor yang paling kecil, artinya pimpinan harus mampu menunjukkan perhatiannya pada bawahan untuk selalu saling berkoordinasi dan berdiskusi mengenai berbagai kegiatan yang dilaksanakan dengan harapan akan memberikan pengaruh peningkatan kinerja pegawai. Gaya kepemimpinan konsultasi dalam kepemimpinan diperlukan untuk mendampingi pegawai dan mengawasi segala pekerjaan yang diberikan sehingga pelaporan dan kegiatan yang ada di organisasi selalu mendapat petunjuk dan pengarahan dari pimpinan yang memberikan pengaruh terhadap kinerja pegawai.

Kepemimpinan identik dengan pengaruh seorang sosok yang mampu menggerakkan massa atau kelompok orang untuk melakukan sesuatu. Kepemimpinan merupakan keahlian atau kemampuan yang dapat diasah oleh setiap orang, oleh karena itu kepemimpinan setiap orang pasti berbeda sesuai dengan pengalaman kegiatan yang sudah dilakukannya, latar belakang keluarga, lingkungan tempat tinggal dan lain sebagainya. Seorang pemimpin tidaklah selalu orang yang dominan, ekstrover atau karakter yang vokal, namun pemimpin identik dengan orang yang bisa mengarahkan, mengambil keputusan, bertanggung jawab, memiliki inisiatif dan dapat merangkul mayoritas anggotanya. Kepemimpinan individu dapat berubah sewaktu-waktu sesuai dengan kondisi saat itu, namun kecenderungan kepemimpinan seseorang akan tetap sama. Kepemimpinan akan selalu menjadi alat dalam mencapai visi dan misi organisasi, perusahaan, individu, komunitas dan lain sebagainya.

Pemimpin yang menunjukkan perilaku-perilaku sesuai dengan harapan akan mendorong para pegawai untuk taat terhadap perintah-perintah pimpinan, sehingga kepemimpinannya menjadi efektif. Kepemimpinan yang efektif memiliki potensi yang berimplikasi pada kinerja aparatur, karena kepemimpinan yang digunakannya dalam mempengaruhi pegawainya dapat berdampak pada perilaku kerja para pegawai yang akhirnya dapat 
membentuk kinerja pegawai. Kepemimpinan yang tidak sesuai dengan harapan mayoritas pegawai akan cenderung direspon negatif oleh pegawai, seperti tidak mentaati perintah, melanggar peraturan, malas dalam bekerja dan perilaku-perilaku negatif lainnya. Sebaliknya, kepemimpinan yang sesuai dengan keinginan pegawai akan cenderung direspon secara positif, seperti bersemangat dalam menjalankan tugas yang diberikan dan mengindahkan aturan-aturan organisasi. Hal itu lebih lanjut dapat mendorong para pegawai untuk menampilkan kinerja terbaiknya.

Hasil penelitian ini sejalan dengan hasil penelitian yang dilakukan Rusady Ruslan (2014), Soleman Aninam (2014) dan Rahmat Asfari (2017). Persamaannya terletak pada variabel yang diteliti yaitu gaya kepemimpinan. Hasil penelitian yang dilakukan oleh Rusady Ruslan dan Rahmat Asfari menunjukkan bahwa gaya kepemimpinan memberikan pengaruh yang positif dan signifikan terhadap kinerja pegawai secara parsial namun tidak secara simultan, sementara penelitian yang dilakukan oleh Soleman Aninam menunjukkan bahwa gaya kepemimpinan hanya memberikan pengaruh yang positif dan signifikan terhadap kinerja pegawai secara simultan tetapi tidak secara parsial. Perbedaan penelitian ini dengan penelitian terdahulu terletak pada hasil penelitian, dimana pada penelitian ini didapatkan bahwa gaya kepemimpinan baik secara parsial maupun simultan memberikan pengaruh yang positif dan signifikan terhadap kinerja pegawai. Indikator variabel dan objek yang diteliti pada penelitian ini dengan penelitian terdahulu juga berbeda.

\section{Pengaruh Motivasi terhadap Kinerja Pegawai}

Hasil analisis secara deskriptif menunjukkan bahwa persepsi responden terhadap motivasi dianggap merupakan faktor yang paling baik pengaruhnya terhadap kinerja pegawai. Hasil analisis regresi linier berganda dan pengujian secara parsial (uji t) terhadap variabel motivasi menunjukkan bahwa motivasi berpengaruh positif dan signifikan terhadap kinerja pegawai. Artinya secara parsial dapat dinyatakan jika terjadi peningkatan atau penurunan pada variabel motivasi maka akan mempengaruhi peningkatan atau penurunan kinerja pegawai secara signifikan.

Pegawai pada Dinas Kependudukan dan Pencatatan Sipil Kabupaten Sinjai menyadari bahwa dalam menjalankan tugas pokok dan fungsinya sangat memerlukan motivasi untuk memperoleh hasil kerja yang maksimal sebagai penilaian kinerja. Artinya wujud pemberian motivasi kerja berupa existence, relationship, growing (ERG) perlu diterapkan untuk mendorong, merangsang atau menggerakkan pegawai agar senantiasa bekerja dengan baik dalam meningkatkan kinerjanya.

Analisis deskripsi variabel motivasi, indikator eksistensi memiliki skor yang paling tinggi, artinya motivasi eksistensi yang diterima oleh pegawai dalam kenyataan keseharian pegawai telah menunjukkan eksistensi diri dengan bersemangat dan bergairah dalam bekerja karena terpenuhinya eksistensi pemenuhan kebutuhan hidup, kebutuhan fisik dan pemenuhan kebutuhan keluarganya, sehingga memberikan pengaruh terhadap kinerjanya. Sedangkan indikator pertumbuhan memiliki skor yang paling kecil, artinya pemberian motivasi pertumbuhan yang selama ini pada pegawai masih dianggap kurang, dimana pengambil kebijakan kurang menunjukkan perhatiannya utamanya pada pemberian penghargaan atau pujian dan pengakuan aktualisasi diri.

Hasil penelitian ini dapat dipahami bahwa motivasi merupakan bentuk dorongan yang mengarahkan pegawai untuk melakukan sebuah aktivitas yang menunjukkan kinerjanya dalam bekerja. Tanpa adanya motivasi, maka tidak akan ada aktivitas, sehingga pegawai akan cenderung pasif. Oleh karena itu, pegawai yang memiliki motivasi kerja tinggi, akan cenderung banyak melakukan aktivitas yang dapat menyebabkan kinerjanya lebih baik. Motivasi juga merupakan kesediaan pegawai untuk mengeluarkan tingkat upaya yang tinggi ke arah tujuantujuan organisasi yang dikondisikan oleh kemampuan upaya untuk memenuhi sesuatu kebutuhan individual. Motivasi dapat berupa eksistensi, keterhubungan dan pertumbuhan. Dengan adanya motivasi, individu akan terdorong untuk mengembangkan kreativitas dan mengaktualkan semua kemampuan serta energi yang dimilikinya untuk menyelesaikan pekerjaan.

Hasil penelitian ini sejalan dengan penelitian yang dilakukan Aurelia Potu (2013), Pariaribo (2014) dan Rizham Syakban (2017). Persamaannya terletak pada variabel yang diteliti yaitu motivasi. Hasil penelitian yang dilakukan oleh Aurelia Potu dan Pariaribo menunjukkan bahwa motivasi hanya memberikan pengaruh positif dan signifikan terhadap kinerja pegawai secara simultan tetapi tidak secara parsial, sementara penelitian yang dilakukan oleh Rizham Syakban menunjukkan bahwa motivasi memberikan pengaruh positif dan signifikan terhadap kinerja pegawai secara parsial namun tidak secara simultan. Perbedaan antara penelitian ini dengan penelitian terdahulu terletak pada hasil penelitian, dimana pada penelitian ini didapatkan bahwa motivasi baik secara parsial maupun simultan memberikan pengaruh yang positif dan signifikan terhadap kinerja pegawai. Indikator variabel yang diteliti dan obyek penelitian yang digunakan pada penelitian ini juga berbeda dengan penelitian terdahulu.

\section{Pengaruh Disiplin Kerja terhadap Kinerja Pegawai}

Hasil analisis secara deskriptif menunjukkan bahwa persepsi responden terhadap disiplin kerja dianggap merupakan faktor yang baik pengaruhnya terhadap kinerja pegawai. Hasil analisis regresi linier berganda dan pengujian secara parsial (uji t) terhadap variabel disiplin kerja menunjukkan bahwa disiplin kerja berpengaruh positif dan signifikan terhadap kinerja pegawai.

Perubahan peningkatan disiplin kerja yang direfleksikan melalui kepatuhan terhadap peraturan yang berlaku, ketepatan terhadap jam kerja, ketaatan terhadap standar kerja, tanggung jawab terhadap hasil pekerjaan dan bekerja etis sesuai prosedur (SOP) memiliki pengaruh 
positif dan signifikan terhadap peningkatan kinerja pegawai yang dicerminkan melalui aspek sasaran kerja pegawai (kuantitas, kualitas, dan waktu) dan perilaku kerja pegawai (orientasi pelayanan, integritas, komitmen kerja, kerjasama dan kepemimpinan). Dengan demikian temuan penelitian ini menunjukkan bahwa disiplin kerja pegawai yang baik memiliki kontribusi yang signifikan terhadap peningkatan kinerja pegawai pada Dinas Kependudukan dan Pencatatan Sipil Kabupaten Sinjai.

Analisis deskripsi variabel disiplin kerja, indikator ketepatan, tanggung jawab dan bekerja etis memiliki skor yang paling tinggi, artinya disiplin dalam hal ketepatan waktu datang dan penyelesaian pekerjaan, tanggung jawab dalam hal melayani masyarakat dengan baik serta bekerja secara etis dan sesuai norma yang berlaku sudah terlaksana. Sementara indikator ketaatan memiliki skor yang paling kecil. Ketaatan terhadap aturan sangat penting karena ketaatan adalah cerminan dari disiplin kerja. Sehingga ketaatan pada aturan perlu ditingkatkan untuk meningkatkan kinerja pegawai.

Peningkatan disiplin kerja memiliki kontribusi nyata terhadap peningkatan kinerja pegawai dan sebagian besar menurut persepsi responden sudah terlaksana dengan baik. Hasil penelitian ini didukung pula dengan karakteristik responden berdasarkan umur para pegawai pada Dinas Kependudukan dan Pencatatan Sipil Kabupaten Sinjai yang berada pada usia yang produktif, sehingga dapat mendukung operasional organisasi. Selain itu mayoritas responden telah memiliki pendidikan terakhir diploma dan sarjana. Kondisi ini menunjukkan tingkat pendidikan pada Dinas Kependudukan dan Pencatatan Sipil Kabupaten Sinjai sudah memadai, sehingga mampu dalam menjalankan tugas-tugas yang diberikan sesuai dengan kemampuannya.

Perubahan peningkatan disiplin kerja merupakan kunci keberhasilan dalam meningkatkan kinerja. Sehingga kinerja pegawai memiliki peranan penting dalam penyelenggaraan pelayanan publik oleh pemerintahan, mempertahankan pegawai berarti mempertahankan kinerja pegawai dan kelangsungan hidup organisasi. Sehingga cukup beralasan bagi setiap organisasi pemerintahan untuk meningkatkan disiplin kerja pegawainya. Kinerja sebenarnya merupakan fungsi kemampuan kerja yang dicerminkan pada kepribadian pegawai. Kemampuan tanpa dukungan disiplin kerja yang tinggi tidak akan menghasilkan sesuatu, akan tetapi walaupun kemampuan kurang, kalau didorong dengan disiplin kerja yang tinggi akan menghasilkan pekerjaan yang lebih baik dan berguna.

Hasil penelitian ini sejalan dengan penelitian yang dilakukan oleh Regina Aditya Reza (2010), Teguh Rhiman Handoko (2012) dan Rio Rizki Pratama (2016). Persamaan terletak pada variabel yang diteliti yaitu disiplin kerja. Dari ketiga hasil penelitian tersebut menunjukkan bahwa secara parsial disiplin kerja berpengaruh positif dan signifikan terhadap kinerja pegawai. Perbedaan antara penelitian ini dengan penelitian terdahulu terletak pada hasil penelitian, dimana pada penelitian ini didapatkan bahwa disiplin kerja baik secara parsial maupun secara simultan memberikan pengaruh yang positif dan signifikan terhadap kinerja pegawai. Indikator variabel yang diteliti dan obyek penelitian yang digunakan pada penelitian ini juga berbeda dengan penelitian terdahulu.

\section{Pengaruh Gaya Kepemimpinan, Motivasi dan Disiplin} Kerja terhadap Kinerja Pegawai

Analisis regresi linier berganda dengan memasukkan semua unsur variabel gaya kepemimpinan, motivasi dan disiplin kerja yang hasilnya menunjukkan adanya pengaruh terhadap kinerja pegawai pada Dinas Kependudukan dan Pencatatan Sipil Kabupaten Sinjai. Nilai probabilitas yang diperoleh pada penelitian ini adalah $0,000<0,005$ dan nilai koefisien determinasi $(R$ Square) sebesar 0,633 yang memberikan arti bahwa besarnya kontribusi dari variabel-variabel tersebut secara bersama-sama berpengaruh terhadap kinerja karyawan sebesar $63,3 \%$ dan sisanya sebesar $36,7 \%$ dipengaruhi oleh variabel lain yang tidak diteliti. Hal ini cukup memberikan keyakinan bahwa variabel-variabel independen tersebut memberikan pengaruh secara bersama-sama (simultan) terhadap kinerja pegawai pada Dinas Kependudukan dan Pencatatan Sipil Kabupaten Sinjai.

Hasil uji $\mathrm{F}$ didapatkan nilai $\mathrm{F}_{\text {hitung }}$ sebesar 14,961 dengan nilai signifikan 0,000 . Karena nilai probabilitas lebih kecil dari 0,05 maka model regresi dapat digunakan untuk memprediksi kinerja pegawai pada Dinas Kependudukan dan Pencatatan Sipil Kabupaten Sinjai. Dari hasil penelitian tersebut dapat dinyatakan bahwa gaya kepemimpinan, motivasi kerja dan disiplin kerja secara simultan memberikan pengaruh positif dan signifikan terhadap peningkatan kinerja pegawai. Selain itu hasil analisis secara deskriptif menunjukkan bahwa persepsi responden terhadap variabel kinerja pegawai sudah baik.

Hasil penelitian ini dapat dipahami bahwa kepemimpinan merupakan salah satu faktor eksternal dalam organisasi yang eksistensinya sangat penting untuk menumbuhkan motivasi kerja, disiplin kerja dan kinerja pegawai. Kepemimpinan merupakan upaya-upaya yang dilakukan oleh seorang pemimpin untuk mempengaruhi perilaku orang lain khususnya pegawai dalam upaya untuk mencapai tujuan. Tindakan- tindakan yang dilakukan pemimpin bervariasi tergantung gaya kepemimpinan yang digunakan. Cara-cara dan tindakantindakan yang dilakukan oleh pemimpin akan menimbulkan persepsi di kalangan para pegawai.

Kepemimpinan yang baik dapat membuat pegawai mau bergerak, termotivasi dan berdisiplin dalam bekerja, serta berdaya upaya secara bersama-sama untuk mencapai tujuan yang ditetapkan. Pimpinan dituntut untuk memiliki kemampuan menggerakkan para pegawai dalam melaksanakan tugas agar tetap memiliki motivasi dan disiplin yang tinggi. Dengan demikian, tugas pimpinan adalah menggerakkan orang lain dan membangkitkan semangat kerjasama dan kedisiplinan yang baik. Apabila pemimpin mampu membangunkan semangat, kegairahan 
dan disiplin bekerja para pegawai maka sikap optimis, tenggang rasa dan suasana kondusif dalam bekerja akan dimiliki oleh para pegawai. Jika fungsi-fungsi yang dimiliki pemimpin seperti sebagai motivator, memberdayakan, manajer, pengawas, dan administrator dijalankan secara efektif, maka akan memberikan implikasi yang positif bagi motivasi kerja dan disiplin kerja aparatur. Khususnya fungsi sebagai motivator, akan memiliki pengaruh secara langsung terhadap tumbuhnya motivasi dan disiplin kerja aparatur. Melalui fungsi sebagai motivator, pimpinan berusaha memberikan dorongan melalui berbagai cara, seperti pujian dan penghargaan. Pujian dan penghargaan sebagai faktor yang cukup efektif untuk membangkitkan semangat kerja aparatur.

Hasil penelitian ini membuktikan bahwa terdapat pengaruh positif dan signifikan gaya kepemimpinan, motivasi kerja dan disiplin kerja terhadap kinerja pegawai pada Dinas Kependudukan dan Pencatatan Sipil Kabupaten Sinjai.

Dominasi Pengaruh Disiplin Kerja terhadap Kinerja Pegawai

Perbandingan nilai unstandardized $\beta$ yang terbesar, maka variabel disiplin kerja memiliki koefisien unstandardized $\beta$ yang terbesar. Oleh karena itu dapat diambil kesimpulan bahwa faktor disiplin kerja berpengaruh dominan terhadap kinerja pegawai dibandingkan dengan dua variabel lainnya.

Hal ini menggambarkan bahwa penegakkan peraturan-peraturan pemerintah dalam hal kedisiplinan pada Dinas Kependudukan dan Pencatatan Sipil Kabupaten Sinjai cukup berhasil, karena disiplin kerja merupakan praktek secara nyata dari para pegawai terhadap perangkat peraturan yang terdapat dalam suatu organisasi. Dalam hal ini disiplin tidak hanya dalam bentuk ketaatan saja melainkan juga tanggung jawab yang diberikan oleh organisasi, sehingga diharapkan efektivitas pegawai akan meningkat dan bersikap serta bertingkah laku disiplin.

\section{SIMPULAN}

Hasil penelitian dan pembahasan dapat disimpulkan bahwa gaya kepemimpinan secara parsial berpengaruh positif dan signifikan terhadap kinerja pegawai pada Dinas Kependudukan dan Pencatatan Sipil Kabupaten Sinjai, hal ini menunjukkan bahwa penerapan gaya kepemimpinan instruksi, konsultasi, partisipasi dan delegasi memberikan kontribusi terhadap peningkatan kinerja pegawai. Motivasi secara parsial berpengaruh positif dan signifikan terhadap kinerja pegawai pada Dinas Kependudukan dan Pencatatan Sipil Kabupaten Sinjai. Ini menunjukkan bahwa setiap pegawai telah terpenuhi motivasi eksistensi, terciptanya interaksi sosial yang harmonis dan pertumbuhan dalam hal ini peluang mengembangkan karir dalam organisasi yang memberikan pengaruh terhadap peningkatan kinerjanya. Disiplin kerja secara parsial berpengaruh positif dan signifikan terhadap kinerja pegawai pada Dinas Kependudukan dan Pencatatan Sipil Kabupaten Sinjai, ini menunjukkan bahwa kesadaran para pegawai terhadap disiplin kerja dalam hal ketepatan, ketaatan, bekerja etis dan tanggung jawab memberikan kontribusi terhadap peningkatan kinerja pegawai.

\section{DAFTAR PUSTAKA}

Aninam, Soleman. (2014). Pengaruh Gaya Kepemimpinan dan Disiplin Pegawai Negeri Sipil terhadap Prestasi Kerja pada Kantor Biro Pemerintahan Kampung Setda Provinsi Papua. Universitas Cenderawasih, Papua.

Arikunto, Suharsimi. (2013). Prosedur Penelitian: Suatu Pendekatan Praktek (Edisi Revisi). Penerbit. Rineka Cipta, Jakarta.

Asfari, Rahmat. (2017). Pengaruh Gaya Kepemimpinan dan Motivasi Terhadap Kinerja Karyawan pada Kantor Imigrasi Kelas I Khusus Medan. Universitas Sumatera Utara, Medan.

Handoko, Teguh Rhiman. (2012). Pengaruh Kepemimpinan, Disiplin Kerja Terhadap Kinerja Karyawan pada Pondok Serrata Hotel. Jurnal Dinamika Manajemen Vol. 1. No. 3.

Hastati, H., Remmang, H., \& Cahyono, C. (2020). Pengaruh Kepemimpinan, Kepuasan Kerja, Quality Of Work Life Terhadap Kinerja Karyawan Melalui Perilaku Di Hotel Dinasti Kota Makassar. Indonesian Journal of Business and Management, 2(1), 35-40.

Hersey, P. and Blanchard, K. H. (2007). Management of Organizational Behavior: Utilizing Human Resources. Prentice Hall, New Jersey.

Kelly, Hat. (2005). The Leadership and the Role in Management. John Wiley and Son Inc., New York.

Moenir, H.A.S. (2005). Manajemen Pelayanan Umum Di Indonesia. Penerbit PT. Bumi Aksara, Jakarta.

Moorhead G, Griffin RW. (2008). Organizational Behavior: Managing People and Organizations. Dreamtech Press.

Pariaribo. (2014). Pengaruh Gaya Kepemimpinan dan Motivasi Kerja terhadap Kepuasan Kerja serta Dampaknya terhadap Kinerja Pegawai pada Badan Perencanaan Daerah di Kabupaten Supiori. Universitas Cenderawasih, Jayapura.

Potu, Aurelia. (2013). Kepemimpinan, Motivasi, dan Lingkungan Kerja Pengaruhnya Terhadap Kinerja Karyawan Pada Kanwil Ditjen Kekayaan Negara Suluttenggo dan Maluku Utara di Manado. Jurnal EMBA Vol. 1 No. 4: 1208-1218.

Pratama, Rio Rizki. (2016). Pengaruh Disiplin Kerja dan Pemberian Kompensasi Terhadap Kinerja Karyawan Bagian Penjualan di PT. Alfa Scorpii Medan. Universitas Sumatera Utara, Medan.

Reza, Regina Aditya. (2010). Pengaruh Gaya Kepemimpinan, Motivasi dan Disiplin Kerja Terhadap Kinerja Karyawan PT. Sinar Santosa 
Perkara Banjar Negara. Universitas Diponegoro, Semarang.

Riduwan. (2007). Skala Pengukuran Variabel-Variabel Penelitian. Penerbit. Alfabeta, Bandung.

Rivai, Veithzal. (2008). Kepemimpinan dan Perilaku Organisasi, Edisi Kedua. Penerbit. PT. Raja Grafindo Persada, Jakarta.

Robbins, Stephen. P. (2006). Perilaku Organisasi. Penerbit. Indeks Kelompok Gramedia, Jakarta.

Ruslan, Rusady. (2014). Pengaruh Gaya Otoriter, Gaya Demokratis dan Bebas terhadap Kinerja Karyawan pada Kantor Pusat PT. Bank Sulselbar Makassar. Universitas Hasanuddin, Makassar.

Stolovitch, Storryl and Keeps, Storey. (2007). Managing Resource and Performance. Open University Press, Buckingham.

Syakban, Rizham. (2017). Pengaruh Disiplin Kerja, Gaya Kepemimpinan dan Motivasi terhadap Kinerja Karyawan pada PT. Bank Sumut Cabang Sukaramai Medan. Universitas Sumatera Utara, Medan.

Thoha, Miftah. (2002). Perilaku Organisasi: Konsep Dasar dan Aplikasinya. Penerbit. Raja Grafindo Persada, Jakarta.

Undang-Undang nomor 43 Tahun 1999 tentang Pokokpokok Kepegawaian. 